\title{
Risk Management and Academic Performance of Public Secondary Schools in Bungoma County, Kenya
}

\author{
Jane Barasa, Sarah Likoko, Pamela Khaemba \\ Department of Educational Planning and Management, Kibabii University, Kenya
}

\begin{abstract}
The purpose of the study was to assess the relationship between risk management and academic performance in schools. The study adopted descriptive survey design. The study was conducted in 360 public secondary schools in Bungoma County. The target population comprised of 360 Principals, 360 Board of management chairpersons and 360 Directors of Studies. The sample size of the study comprised of 72 Principals, 72 Chairpersons of the Boards of Management and 72 Director of studies. Primary data was collected using closed ended questionnaires and checklists. Data was analysed using frequencies, percentages, mean, standard deviation correlation and simple linear regression analysis. The study established that there is a positive and significant relationship between risk management and academic performance of public secondary schools in Bungoma County, Kenya $(r=0.261, p<0.05)$.
\end{abstract}

Keywords: Academic Performance, Risk Management, Public, Secondary schools

\section{INTRODUCTION}

$\mathrm{S}$ chools face risks that compromise the effective conveyance of their goals to educate and protect their students. These risks originate from assortment of sources; because of a characteristic calamity or man-made occasion, episode or mishap (Mackatiani et al, 2014; Mackatiani,2017; Mackatiani et al, 2017; Mackatiani et al, 2018; Mackatiani, 2020; Mackatiani et al, 2020; and Morgan, 2014). UNESCO (2010) argues that because of globalization and an increase in competition, risks are expanding, and managing risk is turning into a necessary part of the achievement of any association. Management of risk is an efficient procedure of dealing with an organization's exposure of risk to accomplish objectives in a way steady with the interest of the public, human wellbeing, natural factors, and the law ISO Guide 73: 2009 (2009).

The International Risk Management: Principles and guidelines on risk management process ISO 31000 (2018) provides guidelines on managing risks faced by organizations, schools are not an exception. The management of risk process comprises a number of steps; identification of risk, analysis of risk, evaluation of risk, risk control measures, monitoring and communicating risks. Identification of risks is considered to be the most important step for risk management (Tchankova, 2002). Analysis of risks is done to determine worth of future evaluation and determine the appropriate risk control measures (Ahamed \& Kayis 2007). According to Crockford \&
Neil (1986) risk control measures involves reducing the likelihood and the impact of risk on an institution by improving management controls and procedures. School safety is an essential part of school risk management. Safety measures are preventive measures to reduce likelihood and impact of risks on students and staff. A safe school environment mitigates threats and risk events that can physically or psychologically harm learners (Kimani, Kara \& Njangi 2013).

In Australia for instance, public schools required that all visitors who checked in at the main office must be issued with identifications which must be put on while in school (Begar, 2002). In addition, these schools had specific guards on duty to monitor school boundaries (Triplett, Trulson \& Snell, 2001). It was noted that in Australia walk- through metal detectors were reported to be in many inner-city schools while hand held detectors, surveillance cameras and random weapons screen were popular in rural schools. Such security measures are unheard of in public schools in Kenya, the excuse being insufficient funds to undertake such activities (Omolo \& Simatwa, 2010).

In Kenya, reports on lack of school safety have been featuring more prominently (Kemunto, Role \& Balyyage (2015). According to the manual of safety standards for schools in Kenya (2008), the wellbeing of students is a focal point in the provision of quality education in any country. This is because learners are entirely defenseless against threats, for example, tormenting, terrorizing, verbal and physical maltreatment and all manner of harassment. Aside from individual threats, insecurity for students can exude from inappropriate facilities at school and infrastructure, playing grounds and classrooms that are poorly constructed, toilets facilities that are either broken down or insufficient, ender insensitivity in facilities like bathrooms and toilets location and inappropriate and inadequate desks and other furniture, slippery surfaces, poor ventilation and hostile school environment among others.

In Kenya the Ministry of Education put in place a regulatory Act which advocates for school safety measures including; installation of serviceable fire extinguishers, decent security arrangement with planning for security during the day and night, all around maintained and tidy up learning rooms and appropriately strengthened fence with a suitable mechanism 
for fixing and upkeep among many other regulations (Republic of Kenya, 2012). However, Nyakundi (2012) affirmed that safety standards and guidelines have not been implemented fully in schools in Kenya due to inadequate financial resources, insufficient training for teachers and students on safety standards and lack of principal's personal initiatives to implement the manual. Apart from safety regulatory Act that advocates for school safety, the Occupational Health and Safety Act of 2007 ensure workplaces such as a school are liberated from perceived dangers to security and wellbeing, for example, exposure to harmful chemicals, exorbitant noise, mechanical risks, heat, extreme cold or heat and unsanitary conditions, overcrowding and air pollution (OSHA, 2007)

The entire procedure of risk management requires commitments from all stakeholders with the institution; students, teachers, parents, BOM and other stakeholders (Ahamed \& Kayis, 2007). Nevertheless, the immediate duty of administering school wellbeing should fall inside a particular school safety committee. According to the manual of safety standards for schools (2008) the members of school safety committee include; BOM chairperson, the principal, Director of studies, teacher in-charge of school safety, and guidance and counseling teacher among others. The current study therefore sought to establish the relationship between risk management and academic performance.

\subsection{Risk Management and Academic Performance}

Several studies have been done on risk management and performance in Kenya and other parts of the world. Many studies on risk management have focused on aspects of modern life and institutions such as finance, health, life, business ventures and project management. A study conducted by Saleem \& Abideen (2010) in Pakistan sought to find out whether effective risk management affects an organization performance. 25 organizations were involved in the study. Interview schedules and questionnaires were used to gather primary data from 135 respondents. In order to come up the relationship between risk management and organizational performance linear regression was used. Findings revealed that some organizations which have systematical processes to deal with risks enjoy high performance. However, Saleem and Abideen (2010) study was conducted in commercial institutions which might limits generalization of results to educational institutions. The current study sought to fill this gap.

Ummu, Jahaini \& Nusaiba (2019) conducted a study on impact of Enterprise risk management implementation on performance in Malaysian public higher education. The study involved 72 Universities of Malaysia. Data was collected using questionnaires. The findings indicated that effective implementation of risk management enhance performance. However, in Ummu, Jahaini \& Nasaiba (2019) study findings were specific for Universities and not basic education institutions. Secondly the study was conducted in a different geographical region. The current study will focus on academic performance in basic education institutions

\section{RESULTS AND DISCUSSION}

\subsection{Relationship between Risk Management and Academic Performance}

The study sought to establish the relationship between risk management and academic performance of public secondary schools in Bungoma County. To achieve this, the researcher enquired in details about the risks faced by schools and the efforts put in to address the risks. All respondents (Principals, BOM chairpersons and DOS) were subjected to similar questions on the checklist and questionnaires. The questions on checklists were measured on nominal scale where responses were either a YES or NO. The questions on questionnaires were measured on a five-point likert scale where 1- Not at all, 2-Less extent, 3-Moderate extent, 4-Large extent, 5-Very large extent. The analysis is shown in table 1 and table 2

Table 1. Risk management and academic performance (responses from checklist)

The respondents (principals, BOM chairpersons and DOS) were required to rate their responses as Yes or No to ascertain the presence or absence of the records

\begin{tabular}{|c|c|c|c|}
\hline Risk Management & \multicolumn{3}{|c|}{ Frequency } \\
\hline $\begin{array}{c}\text { School risk registers } \\
\text { present }\end{array}$ & 88 & 100 & 188 \\
\hline $\begin{array}{c}\text { Yes } \\
\text { present }\end{array}$ & $47 \%$ & $53 \%$ & $100 \%$ \\
\hline $\begin{array}{c}\text { School safety manual } \\
\text { developed }\end{array}$ & 157 & 31 & 188 \\
\hline $\begin{array}{c}\text { School safety policy } \\
\text { present }\end{array}$ & $12 \%$ & $16 \%$ & $100 \%$ \\
\hline $\begin{array}{c}\text { School safety committee } \\
\text { pres }\end{array}$ & 156 & 165 & 188 \\
\hline & $83 \%$ & $17 \%$ & $100 \%$ \\
\hline
\end{tabular}

Source Field data, 2020

From table 1, it can be observed that majority of the respondents represented by $157(84 \%)$ agreed that the schools have safety manual from the Ministry of Education MOEST. Majority of the respondents represented by $156(83 \%)$ agreed that schools have safety committee. However, majority of the respondents represented by 100 (53\%) disagreed that their schools have risk registers. Majority of respondents represented by $165(88 \%)$ disagree that school have developed safety policy. In order to corroborate respondents' views indicated on checklist, it was important to establish the parameter risk management from respondent point of view indicated on the questionnaires the analysis of the respondents' views is shown in table 2 
Table 2. Risk Management and academic Performance (responses from the questionnaires)

The respondents (principals, BOM chairpersons and DOS) were required to rate their opinion on a five-point likert scale where 1- Not at All, 2-Less Extent, 3-Moderate Extent, 4Large Extent, 5-Very Large Extent

\begin{tabular}{|c|c|c|c|c|c|}
\hline Risk Management & $\begin{array}{c}\text { Not } \\
\text { at } \\
\text { All }\end{array}$ & $\begin{array}{c}\text { Less } \\
\text { Extent }\end{array}$ & $\begin{array}{c}\text { Moderate } \\
\text { Extend }\end{array}$ & $\begin{array}{c}\text { Large } \\
\text { Extent }\end{array}$ & $\begin{array}{c}\text { Very } \\
\text { Large } \\
\text { Extend }\end{array}$ \\
\hline $\begin{array}{c}\text { Has your school } \\
\text { experienced any } \\
\text { major risks? }\end{array}$ & 6 & 141 & 18 & 15 & 8 \\
\cline { 2 - 6 } & $3 \%$ & $75 \%$ & $10 \%$ & $8 \%$ & $4 \%$ \\
\hline $\begin{array}{c}\text { Does your school } \\
\text { keep record of risks } \\
\text { which occur? }\end{array}$ & 11 & 136 & 23 & 10 & 8 \\
\cline { 2 - 6 } & $6 \%$ & $73 \%$ & $12 \%$ & $5 \%$ & $4 \%$ \\
\hline $\begin{array}{c}\text { Are major risks } \\
\text { reported to the } \\
\text { BOM? }\end{array}$ & $14 \%$ & $7 \%$ & $73 \%$ & $4 \%$ & $2 \%$ \\
\cline { 2 - 6 } & 29 & 8 & 135 & 8 & 8 \\
\hline $\begin{array}{c}\text { Does the school } \\
\text { implement safety } \\
\text { measures outline in } \\
\text { safety manual }\end{array}$ & $16 \%$ & $4 \%$ & $72 \%$ & $4 \%$ & $4 \%$ \\
\hline
\end{tabular}

Source : Author, 2020

From table 2, it can be observed that majority of the respondents represented by $141(75 \%)$ indicated that to a less extent schools have been experiencing risks. Majority of the respondents represented by $136(73 \%)$ indicated that to less extent the schools keep records of risks which occur.

However, majority of the respondents represented by 137 (73\%) indicated that to a moderate extent major risks are reported to the $\mathrm{BOM}$ for further mitigation measures. Majority of the respondents represented by $135(72 \%)$ indicated that to a moderate extent schools implement safety measures outlined in school safety manual. Descriptive statistics point out that risk management had contributed to academic performance of public secondary schools in Bungoma County to some good extent.

\section{Correlation Analysis}

The study sought to understand the strength and direction of the relationship between risk management and academic Performance. Pearson moment correlation coefficient was adopted to determine if these variables were correlating. The findings were as shown in table 3.

Table 3: Correlation between Risk Management and Academic Performance

\begin{tabular}{|c|c|c|}
\hline \multicolumn{2}{|c|}{} & $\begin{array}{c}\text { Academic } \\
\text { Performance }\end{array}$ \\
\hline \multirow{4}{*}{$\begin{array}{c}\text { Strategic } \\
\text { Performance }\end{array}$} & $\begin{array}{c}\text { Pearson } \\
\text { Correlation } \\
\text { coefficient (r) }\end{array}$ & $.261^{* *}$ \\
\cline { 2 - 3 } & Sig. (2-tailed) & .000 \\
\cline { 2 - 3 } & $\mathrm{N}$ & 188 \\
\hline
\end{tabular}

From table 3, the findings of Pearson Correlation analysis ( $\mathrm{r}=$ 0.261 ); an indication that there is a positive relationship between Risk Management and Academic Performance of public secondary schools in Bungoma County. The study tested whether the obtained correlation coefficient was significant. It was found that $(\mathrm{p}<0.05)$ implying that there is a significant relationship between risk management and academic performance of public secondary schools in Bungoma County.

\section{Testing Hypothesis}

The objective of this study was to determine the relationship between risk management and academic performance of public secondary schools in Bungoma County. In order to achieve this, the study sought to test for the following hypothesis;

$\mathbf{H}_{\mathbf{0 2}}$ There is no statistically significant relationship between risk management and academic performance of public secondary schools in Bungoma County.

Simple linear regression model was adopted to test for this hypothesis and establish the relationship between risk management and academic performance of public secondary schools in Bungoma County. The findings were as shown in table 4.

Table 4. Linear Regression Model: Relationship between Risk Management and Academic Performance

\begin{tabular}{|c|c|c|c|c|}
\hline Model & $\mathbf{R}$ & $\begin{array}{c}\mathbf{R} \\
\text { Square }\end{array}$ & Adjusted R Square & $\begin{array}{c}\text { Std. Error } \\
\text { of the } \\
\text { Estimate }\end{array}$ \\
\hline 1 & $.261^{\mathrm{a}}$ & .068 & .063 & 1.53953 \\
\hline
\end{tabular}

\section{Predictors: (Constant), Risk Management}

From the table 4, it can be observed that adjusted $\mathrm{R}$ value of 0.063 , implying that risk management accounted to nearly $6.3 \%$ of the total variation in academic performance of public secondary schools in Bungoma County. In order to determine whether linear regression model provides a better fit to the data, F- test was computed and results are shown in table 5.

Table 5. ANOVA for Risk Management and Academic Performance

\begin{tabular}{|c|c|c|c|c|c|}
\hline Model & $\begin{array}{c}\text { Sum of } \\
\text { Squares }\end{array}$ & df. & $\begin{array}{c}\text { Mean } \\
\text { Square }\end{array}$ & F & Sig. \\
\hline Regression & 32.265 & 1 & 32.265 & 13.613 & $.000^{\mathrm{b}}$ \\
\hline Residual & 440.848 & 186 & 2.370 & & \\
\hline Total & 473.113 & 187 & & & \\
\hline
\end{tabular}

a. Dependent Variable: Academic Performance

b. Predictors: (Constant), Risk Management

From table 5 , the ANOVA test results were $(\mathrm{F}(1,186)$ $=13.613, \mathrm{p}<0.05)$; an indicator that linear regression model was a good fit to the study dataset. 
Table 6. Regression Coefficients: Relationship between Risk Management and Academic Performance

\begin{tabular}{|l|c|c|c|c|c|c|}
\hline \multirow{2}{*}{ Model } & \multicolumn{2}{|c|}{$\begin{array}{c}\text { Unstandardized } \\
\text { Coefficients }\end{array}$} & $\begin{array}{c}\text { Standardized } \\
\text { Coefficients }\end{array}$ & \multirow{2}{*}{$\mathrm{t}$} & \multirow{2}{*}{ Sig. } \\
\cline { 2 - 5 } & $\beta$ & Std. Error & Beta & & \\
\hline & $\begin{array}{c}3.19 \\
\text { (Constant) }\end{array}$ & .232 & & $\begin{array}{c}13.74 \\
5\end{array}$ & .000 \\
\cline { 2 - 6 } 1 & $\begin{array}{c}\text { Risk } \\
\text { Manageme } \\
n t\end{array}$ & .417 & .113 & .261 & 3.690 & .000 \\
\hline
\end{tabular}

The regression coefficient result results in table 6 show that $(\beta=0.417, \mathrm{t}=13.745, \mathrm{p}<0.05)$; implying that risk management statistically and significantly predicted academic performance hence the study rejected the null hypothesis. Therefore, there is a positive and significant relationship between risk management and academic performance of public secondary schools in Bungoma County.

In addition, risk management had a positive standardized beta coefficient of 0.261 as shown in table 6 . This indicates that a unit improvement in risk management is likely to result to an improvement in academic performance of public secondary schools in Bungoma County. The findings in this study concur with Ummu, Jahaini \& Nusaiba (2019) who conducted a study on impact of enterprise risk management implementation on performance in Malaysian Universities. The study established that implementation of risk management enhances the performance of public Universities in Malaysia. Similarly, Saleem \& Abideen (2010) studied effects of effective risk management on organizational performance of in Pakistan. The study established that some organizations which adopted effective risk management practices enjoyed high performance. The study observed that effective risk management strategies are important for improving the performance of an organization.

\section{CONCLUSION}

The study concluded that there is a positive and significant relationship between risk management and academic performance of public secondary schools in Bungoma County, Kenya $(r=0.261, p<0.05)$. It should be noted that correlation coefficient value $(\mathrm{r}=0.261$ ) was below average of 0.5 , an indicator that risk management was not $100 \%$ efficient in promoting academic performance in public secondary schools in Bungoma County. Risk management accounted for $6.3 \%$ variation in academic performance (adjusted $R$ square $=$ 0.063). In addition, a unit improvement in risk management is likely to result to an improvement in academic performance by $26.1 \%$ (standardized regression coefficient $=0.261$ ). It should be noted that strategic planning was not a sole contributor to academic performance.

\section{RECOMMENDATION}

The study reccommended that the Ministry of Education should intensify routine inspection to ensure that safety standard guidelines are adhered to by public secondary schools. The school managers should capacity build safety committee members to enable them effectively manage risks and ensure safety of learners and staff in school.

\section{REFERENCES}

[1] Kimani, N. G., Kara, M. A. \&Njangi, W. L. (2013). Teacher Factors Influencing Students' Academic Achievement in Secondary Schools in Nyandarua County, Kenya. International Journal of Education and Research, Vol. 1, No. 3, March 2013

[2] Mackatiani et al,( 2014).Peace and development in Africa: prospects and challenges. International affairs and Global strategy, Vol 21 pp 72-78

[3] Mackatiani,C(2017).Influence of examinations oriented approaches on quality education inprimary schools in Kenya. Journal of education and practice(14)pp51-58

[4] Mackatiani et al, 2018;

[5] Mackatiani, C(2020).Conflict and xenophopia in Africa: Implications for peace education. Journal of leadership,Accountability and Ethics17(3)

[6] Mackatiani et al, (2020).African response toquality education:Comparative perspectives on quality primary education in Kenya.European journal of education Studies.vol 6(11) pp313325

[7] Mackatiani,C. Musembi,J. Gakunga, D.(2017). Quality primary education: Implications of Teachers' characteristics. European Journal of education studies Vol.3, No.8, pp 635 -649.

[8] Mackatiani,C. Musembi,J. Gakunga, D.(2018). Learning Achievement: Illusions of Teacher-Centered Approaches in Primary Schools in Kenya. Journal of education and practice Vol.9, No.18, pp $46-54$.

[9] Nyakundi, O. (2012). Implementation of Safety Standards and Guideline in Public Secondary Schools in Nyeri County. (Unpublished M.Ed.). Kenyatta University, Nairobi, Kenya

[10] UNESCO (2010). Risk Management Training. Paris, France: UNESCO.

[11] Ummu, A. R., Juhaini, J \& Nusaibah, M. (2019). An Empirical Study of Enterprise Risk Management Implementation on Performance in Malaysian Public Higher Education. International Journal of Advanced Science and Technology, 29 (9s), 962 - 973

[12] Morgan, C. (2014, July 16). Importance of a Robust School Risk Management Program. Mondaq. https://www.caitlin-morgan.com 